\title{
REPRESENTASI TERHADAP TUKANG PARKIR DALAM PETISI "MALANG DARURAT PARKIR” (SEBUAH ANALISIS WACANA KRITIS)
}

\author{
The Representation of Parking Attendants in the Petition "Malang Darurat Parkir" \\ (A Critical Discourse Analysis)
}

\author{
Devi Kurniasari Riyadi \\ Politeknik Kota Malang \\ devikurniasari29@gmail.com
}
Naskah Diterima Tanggal 8 November 2018-Direvisi Akhir Tanggal 5 November 2019-Disetujui Tanggal 18 Desember 2019 DOI : $10.26499 /$ rnh.v8i2.984

\begin{abstract}
Abstrak
Penelitian ini bertujuan untuk menemukan gaya bahasa yang digunakan untuk merepresentasikan bagaimana tukang parkir dalam petisi "Malang Darurat Parkir" dan menunjukkan mengapa gaya bahasa tersebut digunakan oleh penulis petisi. Petisi "Malang Darurat Parkir" tersedia di laman petisionline.net dan masuk dalam deretan tiga teratas di laman tersebut. Penilitian ini merupakan penelitian kualitatif menggunakan model analisis wacana kritis oleh Van Dijk (2008) yang memiliki tiga aspek yaitu analisa teks, kognisi sosial, dan konteks sosial. Hasil penelitian mengungkapkan bahwa tipe gaya bahasa berdasarkan teori Keraf (2006) yang digunakan adalah diksi, struktur kalimat, dan langsung tidaknya makna dan didominasi dengan representasi buruk atau konotasi negatif, yang disebut juga marginalisasi. Gaya bahasa tersebut digunakan karena dapat diduga Helmy tinggal atau pernah tinggal di Malang, dan kondisi sosial atau orang-orang disekitarnya juga menggunakan jenis kata atau konotasi tersebut.
\end{abstract}

Kata-kata Kunci: Gaya Bahasa, Petisi, Marjinalisasi, Van Dijk, Analisis Wacana Kritis

\begin{abstract}
This research is aimed to find the language style used to represent how the figure of parking attendants in the Petition of "Malang Darurat Parkir" and show why those language styles are used by the writer of petition. Petition "Malang Darurat Parkir" is available in petisionline.net and becomes top three petitions on that webpage. This research is qualitative research by using model of critical discourse analysis by Van Dijk (2008) that has three aspects: text analysis, social cognition, and social context. The results reveal that the types of language style based on theory of Keraf (2006) used are diction, sentence structure, and direct and indirect meaning and all of those dominated by bad representation or negative connotation called marginalization. This language style used because Helmy can be inferred if he lives or ever stayed in Malang city and the confition of social or people around him also use that kind of words or connotation.
\end{abstract}

Keywords: Language Style, Petition, Marginalization, Van Dijk, Critical Discourse Analysis

How to Cite: Riyadi, Devi Kurniasari. (2019). Representasi Terhadap Tukang Parkir Dalam Petisi "Malang Darurat Parkir" (Sebuah Analisis Wacana Kritis). Ranah: Jurnal Kajian Bahasa, 8 (2), 237-254. doi: https://doi.org/10.26499/rnh.v8i2.984 


\section{INTRODUCTION}

Petition can be one medium to deliver people's aspiration to the highest authority or government. Lindner \& Riehm (2009) stated that petition contains about a demand and aspiration from society to public authority such as government related to certain policies. The purpose is to change public policy or to encourage certain action made by public institution. Nowadays, petition can be made and published through online web that is called online petition (e-petition). One example of e-petition platform is petitionline.net. One of petitions published by petitiononline.net was Petition of "Malang Darurat Parkir" ("Malang Emergency of Parking (Attendants)"). It is a petition written by Helmy. This petition contained about how he was disturbed by the parking attendants which are excessive in Malang. Most of public places in Malang always be waited by parking attendants. It means that if people ride the vehicle both motorcycle or car, and they stop and park their vehicle, they have to pay some money to the parking attendants. Moreover, the content of the petition shows the reader how is the figure of parking attendant in Malang. Surprisingly, until November $8^{\text {th }}, 2018$ it has been 11.211 the total signatures for this petition and become the top 3 of petition in that platform. It shows that Helmy as the writer succeeded to convince other people agree with him.

The purpose of petition is to get attention from society in order to agree to the petition so that it can be read by public authority. That is why the use of language such as the choice of words and the arrangement of sentences can influence whether the petition can attract other people or not. This petition, the representation of parking attendants is clearly shown. As stated by Siswono (2014), style or language style is a language idea that can be set in such a way by speaker or writer to get more attention to other. Moreover, this idea is in line with Keraf (2006) who said that language style can be functioned to reveal the thought through the specific language which shows the soul and personality of the language user.

Bakti (2017) has conducted a research about discourse analysis in petition of "Tolak RUU Pilkada" and "Tolak Revisi RUU MD3" from the website www.change.org. The researcher used discourse analysis method by Norman Fairclough (1995) to analyze the petitions. The research revealed that the politic participation in website change.org had meaning shifting and the texts produced by the writers in the petitions indicated nationalism. Another research has been conducted by Dewi \& Maulana (2015) entitled 
“Diskursus Cyberbullying Florence Sihombing (Analisis Wacana Kritis Teun A. Van Dijk Tentang Florence Sihombing di Dunia Maya) (A Discourse of Cyberbullying on Florence Sihombing: Critical Discourse Analysis Teun A. Van Dijk about Florence Sihombing in Cyberspace)." They have conducted a critical discourse analysis by using Van Dijk's method. The result of the study showed that cyberbullying that happened to Florence can be explained by some elements proposed by Van Dijk, those are thematic, schematic, semantic, syntactic, stylistic, and rhetoric. The present study is interested in conducting research in online petition by using critical discourse analysis model on Van Dijk. However, the researcher is aimed to find the language style used and why those are used to represent how the figure of parking attendants in petition “Malang Darurat Parkir" by using Critical Discourse Analysis model of Van Dijk that has three aspects those are text analysis, social cognition, and social context.

\section{THEORETICAL BASIS}

\section{Critical Discourse Analysis by Van Dijk}

Critical Discourse Analysis (CDA) is a critical, perspective on doing scholarship or discourse analysis "with an attitude" which focuses on social problems and especially on the role of discourse in the production and reproduction of power abuse or domination. Moreover, it takes the experiences and opinions of members of such groups seriously, and support their struggle against inequality (Wodak \& Meyer, 2001).

One of the models or methods on CDA has been described by Van Dijk (2008). Discourse according to Van Dijk was described by three dimensions, those are text, social cognition, and social context (Eriyanto, 2001). Model of Van Dijk's analysis can be also described as follow:

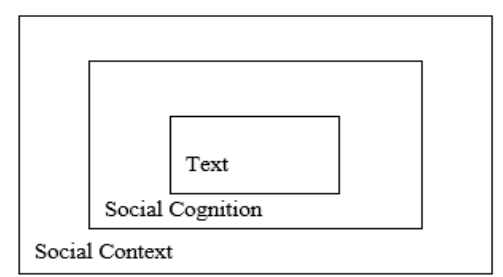

Picture 1. Analysis Model by Van Dijk (taken from Darma, 2009)

a. Text

Van Dijk has seen a text consist of several structure or level which support each other. He divided into three levels. First, macro-structure. It is general meaning 
of a text which can be observed by looking at the topic or theme. Second is superstructure. It is a discourse structure which deals with text design, how parts of text are arranged into a fully report. Third is micro structure which is a discourse meaning that can be observed from small parts of text such as word, sentence, proposition, and other rhetorical elements that provide coherence in text (Bukhari \& Xiaoyang, 2013).

b. Social Cognition

Social cognition is a dimension to explain how text is produced by individual or group. The way to view and observe a social reality can produce a text. Moreover, Wodak \& Meyer (2001) added that knowledge, attitudes, ideologies are various forms of social cognition. This cognitive function becomes a form base of ideology properties which organize, monitor, and control attitudes from social group (Ramanathan \& Hoon, 2015).

\section{c. Social Context}

Social context sees how the text is interlinked further with social structure and develop knowledge in society on a discourse (Eriyanto, 2001).

\section{Language Style}

According to Keraf (2006), the word 'style' is an ability and expertise to write or use the words attractively. As development, the language style becomes a problem or part of diction or choice of a word which is dealing with the appropriateness of using word, certain phrase or clause in facing a certain occasion.

As it is seen from language side and element, the types or classifications of language style can be divided into as follow:

\section{Language Style Based on Diction}

Based on Diction, language style concerns about which word is appropriate to certain position in a sentence (Keraf, 2006). Keraf (2006) divided language style based on diction into some classifications, those are abstract word, concrete word, general word, specific word, popular word, scientific word, and idiom. According to Keraf (2006), abstract word is a word which refers to a concept which is difficult to be described by senses, while it is contrast to concrete word that is a word which refers to actual noun and can be easily described by senses. Keraf (2006) also classified language style into general and specific words. General word is a word which refers to wide range and has general 
meaning, while specific word is a word which refers to narrow range, is more specific and detail than general word and specific word will not cause a misunderstanding. Other language styles based on diction according to Keraf (2006) are popular and scientific word. Popular word is a word which is used in daily activity and communication by all of people while scientific word, it is a word which is usually used for scientific importance such as scientific writing, special and specific discussions and usually used by certain groups of people especially educated group of people. The last one is idiom. Idiom is structural patterns which diverge from the norms of general language, and usually in the form of phrase and cannot be explained the meaning logically or grammatically and focus on the meaning from the words formed (Keraf, 2005).

\section{Language Style Based on Sentence Structure.}

According to Keraf (2006), sentence structure here means the way the sentence is arranged and how to place an element which is considered important in that sentence. There is a sentence which is periodic, loose, and balanced. Priyanto (2016) added that sentence structure can be as a basis to create a language style. Sentence structure can be climax, anticlimax, parallelism, antithesis, and repetition.

\section{Language Style Based on Direct and Indirect Meaning.}

The language style based on the indirect meaning is called as trope or figure of speech which means "opposition" or "deviation" and the language style which is called as figure of speech can be classified into two groups; rhetorical language style and figurative language style (Keraf, 2006).

a. Rhetorical language style based on Keraf (2006) is deviation from the common construction of language to achieve certain effects. According to Keraf (2006), the types of rhetorical language are (a) alliteration, (b) assonance, (c) anastrophe, (d) apophasis, (e) apostrophe, (f) asyndeton, (g) polysyndeton, (h) chiasmus, (i) ellipsis), (j) euphemism, (k) litotes, (l) hysteron, (m) pleonasm and tautology, (n) periphrasis, (o) prolepsis and anticipative, (p) erotesis or rhetorical question, (q) syllepsis, (r) correction, (s) hyperbole, (t) paradox, (u) oxymoron.

b. Figurative language style is further meaning deviation, especially in describing the meaning of word or phrase (Keraf, 2006). He divided the figurative style into several types, those are (a) similarity or simile, (b) metaphor, (c) allegory, (d) pable or fable, (e) personification, (f) allusion, (g) eponym, (h) epithet, (i) 
synecdoche, (j) metonymy, (k) antonomasia, (l) hypallage, (m) irony, cynicism, and sarcasm, (n) satire, (o) innuendo, (p) antiphrasis, (q) pun or paronomasia.

\section{Ideology}

Ideology is usually associated with various notions of power and dominance or, ideology can be defined as something of social beliefs that organize and coordinate the social interpretation and practices of groups and their members, and in particular also power and other relation between groups (Dijk, 1998). Eriyanto (2001) added that in this perspective, ideology has some important implications. First, ideology has social characteristic, not personal and it needs share between group member, organization, or other collection of people. This group may have ideology of feminism, antiracism, and pro-environment. Second, although ideology has social characteristic, it is used internally in member group or community. In news text for example, the ideology of someone can be seen whether he/she is feminism, antifeminism, capitalist, socialist, and so on.

In addition, ideology can evict the ideas of certain people or group. At this point, representation is important to be discussed. According to Fiske (1990) as cited in Eriyanto (2001) when we make representation, it can be avoided that we are still using the ideology. Further in representing, it probably happens to misrepresent of describing something. Someone, group, and idea are described in bad way. This term called misinterpretation. There are at least five points of misinterpretation that may appear those are ex-communication, exclusion, marginalization, and delegitimacy.

\section{RESEARCH METHOD}

This research was conducted by using qualitative approach, because the data in the form of text and the result of the research is a description of language style in Petition "Malang Darurat Parkir" and the ideology used by the writer of the petition.

The data used for this research is texts or sentences of petition entitled "Malang Darurat Parkir" written by Helmy that represent or show the figure of the parking attendants and the text is in Bahasa Indonesia. The data source of this research is taken from www.petisionline.net which uploaded on September 11, 2016.

The petition was collected from the internet from webpage $w w w$.petisionline.net and in analyzing the data the researcher used method or model of critical discourse 
analysis by Van Dijk which has three aspects, those are text analysis social cognition, and social context. In data analysis, the researcher used these following steps:

1. A. Reading the text carefully.

B. Numbering every sentence in petition.

C. Underlining the text that represent the figure of parking attendants.

2. Finding the pattern of language style in presenting how the parking attendants.

3. Explaining the data about why the writer used those language syles.

\section{DISCUSSION}

This part consists of three sub-parts: text analysis, social cognition, and social context. Text analysis contain of language use style found in petition supported with the analysis. Social cognition and social context contains the reason why the writer of petition use the language style as it. Moreover, these sub-parts also contain the possible ideology and thoughts used by the writer of petition.

\section{Text Analysis}

\subsection{Language Style Based on Diction}

From the Petition "Malang Darurat Parkir", it is found the language style based on diction that involves abstract and concrete words, general and specific words, popular and scientific words, and idiom. The description of those classifications of words are displayed with the source text then explained by some analysis.

a. Abstract Words

The use of abstract words can be found in six sentences. From those six sentences, it is found ten abstract words those are sudut / spot (n), hak / right (n), masyarkat / citizen (n), kewajiban / duty (n), kadang / sometimes (adv), beberapa / a few (det.), sesuatu / something (n), sesekali / ocasionally (adv), semua / all (det.), sejumlah / amount (n). The repetition of words happen in difference sentences, the words are kadang / sometimes (adv) and sudut / spot (n). These are some examples of sentences which contain of abstract words:

(9) [Kadang sesekali kita coba tidak membayar dan akhirnya adu mulut pun tak terhindarkan] (Sometimes, occasionally we try to do not pay and finally the argument (between the rider and parking attendants) can not be avoided)

The ninth sentence of the petition shows the badness of parking attendants, the abstract words use on that sentence are kadang / sometimes (adv) and sesekali / 
occasionally (adv). Those shows abstract because it is difficult to specify when it happens which is shown by kadang / sometimes and how many times which is shown by sesekali / occasionally. It is because the class of abstract words as adverb, especially adverb of time.

Another sentence which is also shown the badness of parking attendants and contains abstract word is:

(13) [Kami sudah bosan jika setiap berhenti membayar sejumlah uang] (We are tired of paying some money for every stop)

That sentence contain of abstract word sejumlah / some (adj). 'Some' here is a number, quantity of money, but it is not described how many numbers, or how much money that the rider should pay.

From the abstract words found in the petition, it is dominated by the description of number or quantity such as 'a few', 'all', 'some'.

\section{b. Concrete Words}

It is found six sentences contain concrete words. Those are parkir / park (v), berhenti / stop (v), dipaksa / forced (v), membayar / pay (v), dikasih / was given (v), uang / money (n), jual beli / buy and sell (v), dengar / listen (v), berhenti / stop (v). The word membayar / pay (v) is mentioned several times in different sentences. These are two examples that contain concrete words.

(5) [Kadang kita hanya beberapa menit berhenti, membeli sesuatu tak sampai seribu rupiah kami tetap di paksa untuk membayar melebihi apa yang telah kami beli] (Sometimes, we only stop in a few minutes, to buy something which is not more than one thousand rupiah, we are forced to pay more than what we have bought)

This sentence consists of four concrete words, those are berhenti / stop (v) which means stop moving or operating, membeli / buy (v) means pay someone to give up an ownership, interest, or share, dipaksa / forced (v) which means drive or push into a specified position or state using physical strength or against resistance and this word show one of the badness of parking attendants, and membayar / pay (v) give (someone) money that is due for work done, goods received, or a debt incurred.

(7) [Sedang kewajiban sebagai tukang parkir setelah di kasih uang langsung pergi_begitu saja] (While, their obligation as parking attendants, after they are given some money, they just go directly)

This seventh sentence has three concrete words. First word is dikasih / was given (v) which means handed over (an amount) in payment; pay. Moreover, the word dikasih 
is informal word, the formal one is diberi. Second one is uang / money (n) which is a current medium of exchange in the form of coins and banknotes; coins and banknotes collectively.

From the data found (5 and 7) above, the concrete words consist of one noun and ten verbs. The major verbs used are transitive verbs, which mean the verb that needs object or force the owner of vehicle to do something such as the words membeli / buy, dikasih / given, dipaksa / forced, dengar / hear, membayar / pay. Moreover, there are several verbs which are repeated from one sentence in other sentences.

\section{c. General Words}

There is only one general word found from the petition. It is found from this sentence 7 .

(7) [Sedang kewajiban sebagai tukang parkir setelah di kasih uang langsung pergi begitu saja] (Meanwhile, their obligation as parking attendants are not fulfilled after money given, they directly go)

The sentence contains the general word pergi / go (v). The word pergi / go (intransitive verb) which means move from one place to another; travel, has several other specific words such as meninggalkan / leave (v), berangkat / depart, bertolak / depart, and keluar / out.

\section{d. Specific Words}

It is found 12 specific words from nine sentences in the petition. Those are kota Malang / Malang (n), lahan parkir / parking area (np), ATM / Authorized Teller Machine area (np), warung makan kecil / small food stall (np), tempat fotokopian / copy place (np), tukang parkir / parking attendants (np), menit / minute (n), seribu rupiah / one thousand rupiah (np), dua ribu / two thousand rupiah (np), sepeda motor / motorcycle (n), peluit / whistle (n), luput / escape (v). There are words are frequently repeated such us kota Malang / Malang (n), and tukang parkir / parking attendants (np). These are some examples which show sentence containing specific words.

(1) [Masalah tentang "PARKIR" di kota malang, menjamurnya lahan parkir sangat meresahkan kami]. (Problem about "PARKING" in Malang, there are so many illegal parking lots that make us fidget less)

Sentence 3 above contains specific word that is kota Malang / Malang (n). It shows specific place where or in what city the action happens. Malang is a name of city located in east Java. 
(8) [Mulai dari ATM, Warung makan kecil bahkan tempat fotokopian, setiap ada transaksi jual beli di kota malang ini, semua tak luput selalu saya dengar peluit parkir] (From Authorized Teller Machine area, small food stall, to copy place, in every place where the transaction of selling and buying in Malang, it can not be escaped with the whistle of parking attendants)

Sentence 8 above containing specific words, those are lahan parkir / parking area, ATM / Authorized Teller Machine area, warung makan kecil / small food stall, tempat fotokopian / copy place which shows specific place where there are transaction of money. Kota Malang / Malang (n) also classified as specific word because it shows the specific name of place or city. One another specific word is peluit / whistle. It produces a sound by blowing on tool. The writer used the specific noun to describe a tool.

So, in conclusion, specific words found are the noun (n) and noun phrase (np) that show city, time, money, vehicle, place, and occupation/profession. Actually from these types, it can be said that the 'victim' from the parking attendants is the citizens who live in Malang city. Most of citizens, especially the writer of petition ride the motorcycle which should pay two thousand for every parking although in a few minutes stop, Not only in big public places, but in small public places, there are the parking attendants.

\section{e. Popular word}

The popular word is found in the sentence:

(2) [Masalah tentang "PARKIR" di kota malang,menjamurnya lahan parkir sangat meresahkan kami] (Problem about "PARKING" in Malang, there are so many illegal parking lots that make us fidget less)

The word masalah (problem) is categorized as popular word because Indonesian people tend to use this word instead of problematika (problem) which is considered as scientific word. Moreover, this noun word explains that the parking area with its parking attendants in huge amount become the problem for citizens.

\section{f. Idiom}

Idiom word found in the sentence:

(9) [Kadang sesekali kita coba tidak membayar dan akhirnya adu mulut pun tak terhindarkan] (Sometimes, occasionally we try to do not pay and finally the argument (between the rider and parking attendants) can not be avoided)

There is one idiom word found from petition "Malang Darurat Parkir", that is $a d u$ mulut (argument / debate). The idiom phrase usually uses part of body to represent the word. It uses 'mouth' in above sentence, but actually it has connotative meaning. The 
word 'mouth' means that between the citizen and parking attendant will argue with each other.

In conclusion, based on diction, the writer frequently used specific words in the sentences which represent the figure of parking attendants. It seems that the writer of petition is willing to show directly what he felt and the readers of petition will understand clearly what he think about.

\subsection{Language Style Based on Sentence Structure}

There are three kinds of language style based on sentence structure found in petition, those are anticlimax, antithesis, and repetition.

a. Anticlimax can be found in the sentence 8:

(8) Mulai dari ATM, warung makan kecil bahkan tempat fotokopian, setiap ada transaksi jual beli di kota Malang ini, semua tak luput saya dengar peluit parkir (From ATM area, food stalls, until copy place, in every place where the transactions exist in Malang, it can not be escaped by the whistle of parking attendants).

This sentence can be called anticlimax because the writer of the petition put the name places from most important to less important thing. Those can be shown from the transition signal mulai (start from), and bahkan (even), those things here are emphasized to the name of places that usually the parking attendants exist. Moreover, this sentence shows the cohesion text.

b. Antithesis can be found in the sentence (6) and (7):

(6) and (7) [Kita diwajibkan membayar 2rb sekali berhenti untuk sepeda motor. Sedang kewajiban sebagai tukang parkir setelah dikasih uang langsung pergi begitu saja]. (We are obligated to pay two thousand rupiah for one time when we park the motorcycle. While, their obligation as parking attendants are not fulfilled after money given, they directly go)

Sentence 6 and 7 can be called as antithesis because the word sedang (while). Moreover, these sentences tell about the contradictory between the obligation of the drivers and the parking attendants. The drivers fulfill their obligation, but not for the parking attendants.

c. Repetition can be found in the words siluman parkir in the sentence (3) and (4):

(3) and (4) Setiap sudut kota Malang tak pernah luput dari siluman parkir. Kenapa saya sebut siluman parkir, karena antara hak kita sebagai masyarakat dan kewajiban sebagai tukang parkir tak pernah imbang (every spot in Malang city never escape from parking stealth. Why I call as parking stealth, because between our right as citizen and their obligation as parking attendants never balance). 
The repetition can be found in the words siluman parkir (parking stealth). This repetition actually has negative connotative which refers to the parking attendants.

\subsection{Language Style Based on Direct or Indirect Meaning}

These three types of Language Style Based on Indirect Meaning, those are epithet, innuendo, and irony.

a. Epithet

Epithet is a characterizing word or phrase applied to or replace a name of a person or thing to describe an actual or attributed quality. The words or phrases in petition that contain epithet are siluman parkir (stealth parking) and preman pungli (illegal charges thug) in sentence (3), (4), and (10). These are a name or label which is given to parking attendant or the man who help the driver to put their vehicle in order. This label contain of negative connotation meaning because the use of the words siluman (stealth), preman (thug) and pungli -pungutan liar- (illegal charges).

b. Innuendo

Innuendo is like a satire when someone says something innocent and impolite on the surface, but indirectly he/she delivers a rude comment or criticism. It can be found in the sentence:

(8) [...setiap ada transaksi jual beli di kota Malang ini, semua tak luput saya dengar peluit parkir] (in every places where the transaction of selling and buying in Malang, it can not be escaped with the whistle of parking attendants)

It means that after people having transaction (selling and buying in a store) or transaction of money, it always listens a sound from parking attendant's whistle that means they have to pay for parking of their vehicle.

c. Irony

Irony is found in the sentence:

(5) [Kadang kita hanya beberapa menit berhenti, membeli sesuatu tak sampai seribu rupiah kami tetap dipaksa untuk membayar melebihi apa yang telah kami beli] (Sometimes we only stop for a second to buy something which is not more than one thousand rupiah, we are still forced (by parking attendants) to pay more than what we have bought).

Irony is used to express contradictory attitude or intention. Here means that, this person actually can save more money because the purchased item that he/she bought is 
cheap, in fact because there is parking man, this person should spend more money or more expensive than the purchasing item.

Not all people will know directly if someone uses any figurative language style or indirect meaning. Moreover, it needs attention, especially to catch real meanings which the producer of text wants to convey (Aflalah, 2017). But here, if the readers read all the text and especially they are also Malang citizens, they can know easily what is implied in text though the petition uses figurative style. From the analysis above, the language style types found in the petition "Malang Darurat Parkir" are diction, sentence structure, and indirect meaning. Based on the language style used, the parking attendants, especially the illegal parking attendants in the petition are represented by the bad figure. It can be shown by the diction, sentence structure, and direct and indirect meaning that Hemly used. Helmy represents the parking attendants are people who always force (to pay with money), exist in many public places there are transaction of sell and buy or even in ATM area, like to argue (if the riders do not want to pay). Moreover, the use of figures of speech that contain negative connotation appear in the petition, those are preman pungli and siluman parkir which are mention repeatedly. This connotation terms can be called as marginalization.

Moreover, in sentence structure the coherent analysis is found in the form of antithesis that is the usage of the word sedang / while between two sentences. It means between two sentences shows different activities between the drivers who park their vehicle and the parking attendants. The drivers have fulfilled their obligation on paying the parking fee, but not for the parking attendants. They just leave the driver after they get the money.

\section{Social Cognition}

Social cognition based on Van Dijk (2008) model emphasizes how the event is understood and interpreted in a model of memory and is based on the value or belief which is in the society. This part also reveals why the text was produced so it can answer second research question that is why those language styles are used in the petition.

\subsection{Role}

The role of Helmy here can be described as someone brave. Because he is the one only man who is brave to deliver his thought and it represents what other Malang citizens 
have. Other Malang citizens responded to this petition positively and support what Helmy wrote. It can be seen that it has been 11. 211 total of signature on this petition. He delivers him though in petition based on what he saw and experienced. It can be seen from the use of the form verb in his petition.

\subsection{Person of helmy}

The writer or creator or language user of the petition "Malang Darurat Parkir" is Helmy. It is unknown what Helmy is. However, it can be inferred that Helmy is someone who is from and live at Malang. It can be shown from the words that he used in his petition, most of words are dominated with specific words. It means he knows fully how these parking attendants are fidgety. It can be shown by some of parking areas or places where usually the parking attendants exist are mentioned specifically like ATM / Authorized Teller Machine area, warung makan kecil / small food stall, tempat fotokopian / copy shop.

Helmy as the writer of petition also represent the parking attendants with negative connotation or bad representation that he repeated in several sentences in petition, those are siluman parkir (stealth parking) and preman pungli (illegal charges thug). Another verb or diction that shows how bad the parking attendants is dipaksa / are forced, or the riders who stop their vehicle are forced to pay the parking. It seems that the writer used marginalization in represent the parking man. Marginalization is bad representation to another group and ostracizes the role of certain group (Eriyanto, 2001).

\subsection{Believe on Society}

The bad representation is not only used by Helmy to represent the parking attendants in Malang. Other Malang citizen also used this terms or same style as it has done by instagram user from his account @yudisumajadi on November 22, 2017. In his caption, he wrote: "Ada tulisan bebas parkir tapi ada preman markir...” (There is Free Parking sign but the thug parks), with some hash tags \#parkirliarmalang \#premanparkir \#premanparkirmalang. This user of account used the figure of speech parking 'thug' to represent parking attendants. In addition, another instagram account, named @adhe.kurniawan.1808 wrote this caption: tukang parkir bukan, tiap motor dimintain duit \#silumanparkir (not parking man, but every motorcycle is aske money 
\#parkingstealth). Again, the bad representation was used here, it is siluman parkir (parking stealth). Those words preman siluman have connotation meaning. Moreover, in the instagram caption, there is the word dimintain (duit) / is asked for (money) that contains concrete word to show the bad activity of the parking attendant. While, in the petition, Helmy used the word dipaksa / forced. So, it is not surprising if the negative connotations are produced among these people, include Helmy.

Marginalization in Indonesian people not only represents in real-world like the parking attendant, but also used by parliament leader to represent another institution. Based on a research condecuted by Kusno and Bety (2017), Fahri Hamzah is one of parliament leaders who often criticizes the Corruption Eradication Commision (KPK) through his Twitter account with negative connotation. Another marginalizaion or negative connotation also found in literature work such as song. Related to this, there was a research conducted by Setiowati \& Wahyuningtyas (2011), entitled Marjinalisasi Perempuan Pertama Melalui Lagu: Suatu Analisis Wacana Kritis Terhadap Lagu "Jadikan Aku yang Kedua” (Marginalization of First Women through Song: A Critical Discourse Analysis on Song: “Jadikan Aku yang Kedua”). The song Jadikan Aku yang Kedua tells that this song legalized polygamy. The result reveals that the song shows the first position women are marginalized, while the second women is empowering them. A literature work also reflects about the writer. The writer of the song is a man. He has the power to shape ideology of listener of the song through his patriarchal ideology. Not only in song marginalization has also appeared in representing career women in Kartini magazine at consultation rubric (Muhammad \& Sumarlam, 2018). Therefore, the culture of marginalization of certain groups is like something common for people.

\section{Social Context}

This part discusses how the text is interlinked further with social structure and develop knowledge in society on a discourse.

\subsection{Power practice}

Helmy is a usual Malang citizen who is powerless in doing a change in power practice. He used petition to deliver his willingness. Petition is a demand for the powerful authority that contains on aspiration delivered by an individual. Usually, petition is made because there is unacceptable policy of a dominance. The dominance is sure to those in 
government. The government has its own rule about parking regulation. The parking regulation has been made, it is based on Peraturan Daerah No. 3, 2015 about parking retribution and Peraturan Daerah about management of parking area. However, as it can be seen that these regulation are still weak, because the content of petition focused more on the parking attendants, which is it has not regulated yet.

\subsection{Access}

Petition of "Malang Darurat Parkir" was published on petisionline.net where people can give their signature by giving their one of social media accounts (for example Facebook). Until November $8^{\text {th }}, 2018$, the total of signature is 11.211. Moreover, this petition has become third popular petition on that website among all petitions that have been created. It can be inferred that Helmy can convince the citizen by the language that he used and the citizen feel the same experience on what Helmy said in the petition. In addition, this petition can be access for Malang citizen to the government to control the parking attendants.

After this petition was published, many media, both from local media in Malang and national media, preach and respond to this petition. From the news published on detiknes.com on September 12, 2016, through the head of Public Relation Department Nurwidiyanto, Abah Anton (the mayor of Malang city at that time) said that the petition "Malang Darurat Parkir" is one of input from citizen about the situation of Malang city. He also added that "The government will not completely remove the parking and change it into electronic parking, because that is their source of income, but if there is an illegal tariff or charge, let us fight for it together."

Responding to the petition especially illegal tariff or charge like what Helmy wrote in petition, the government of Malang, in this case is Abah Anton, inspected to illegal parking attendants. The video of inspection done by Abah Anton also uploaded in his social media account, instagram: @abahanton_n1.What Abah Anton done was like the answer and respond for Malang citizens who are disturbed by the presence of parking attendants, especially there was the petition entitled Malang Darurat Parkir (suratkabar.id). In the petition it is also like a command to the government to control the parking attendants, it can be shown the use of word: "tertibkan" (put in order) that appears on the petition. Not only showing his inspection but, Abah Anton also wrote a message 
to the citizen to do not pay to the parking attendants if they are not complete themselves with ID card and parking ticket card. Like what Abah Anton wrote his Instagram caption, "Saya minta masyarakat jangan mau bayar kalau tidak ada tanda pengenal dan karcis resmi" (I asked the citizen to do not pay (the parking), if there is not ID card (on parking attendant) and legal ticket.

\section{CLOSING}

Every discourse has its language style, include discourse in petition. Petition "Malang Darurat Parkir" contains language styles such as diction which is dominated with specific word, sentence structure, and indirect meaning that revealed from the figure of speech. Moreover, from the petition, the parking attendants are represented with bad figure and bad connotation expression or it is called marginalization. Those kinds of language style used because Helmy is a person who stays in Malang because he knows specifically how bad the parking attendants and in which places usually parking attendants exist. Moreover, people around Helmy has also the same style in representing the parking attendants that is marginalizatition on parking attendants. So, it is not surprising if the petition contains some words which are badly used by Helmy.

\section{BIBLIOGRAPHY}

Alfahah. (2017). Language Style of Habiburrahman El-Shirazy in the Dwilogy of Ayat-Ayat Cinta: A Stylistic Study. OKARA: Jurnal Bahasa dan Sastra Vol. 1; 85-122. Retrieved on http://ejournal.stainpamekasan.ac.id/index.php/okara/article/download/1239/891 on May 3, 2018

Bakti, F. (2017). Analisa Wacana Partisipasi Politik pada Petisi "Tolak RUU Pilkada" dan Petisi "Tolak Revisi RUU MD3". Commonline Departemen Komunikasi, Vol. 4 No (2). Retrieved from http://journal.unair.ac.id/download-fullpapers-comm9db9990d41full.pdf on May 3, 2018

Bukhari, N. \& Xiaoyang, W. (2013). Critical Discourse Analysis and Educational Research. Journal of Research \& Method in Education. Vol 3; 09-17. Retrieved from http://www.iosrjournals.org/iosr-jrme/papers/Vol-3\%20lssue-1/B0310917.pdf on October 28,2018

Dewi, S. \& Maulana, S. (2015). Diskursus Cyberbullying Florence Sihombing (Analisis Wacana Kritis Teun A. Van Dijk Tentang Florence Sihombing di Dunia Maya). Jurnal Ilmiah Komunikasi 5 (2); 114-127. Retrieved from http://jurnal.unissula.ac.id/index.php/makna/article/view/2133 on October 13, 2018

Dijk, T. (1998). Ideology. London: SAGE Production.

Darma, Y. (2009). Analisi Wacana Kritis. Bandung: Yrama Widya

Eriyanto. (2001). Analisa Wacana: Pengantar Analisis Teks Media. Yogyakarta: LkiS

Keraf, G. (2006). Diksi dan Gaya Bahasa. Jakarta: PT. Gramdia Pustaka Utama 
Kusno, Ali. \& Bety, Nur. (2017). Analisis Wacana Kritis Cuitan Fahri Hamzah (FH) Terkait Hak Angket Komisi Pemberantasan Korupsi (KPK). Jurnal Ranah 6(2): 137-159). DOI: https://doi.org/10.26499/rnh.v6i2.462

Muhammad, H. \& Sumarlam. (2018). Marjinalisasi Wanita pada Rubrik Konsultasi Karier dalam Majalah Kartini: Tinjauan Analisis Wacana Kritis. Jurnal Akrab Juara 3(3): 226-239). Retrieved from http://akrabjuara.com/index.php/akrabjuara/article/view/289/221 on October 28, 2018

Ramanathan, R. \& Hoon, T. (2015). Applcation of Critical Discourse Analysis in Media Discourse Studies. The Southeast Asian Journal of English Language Studies. Vol 21(2): 57-68. Retrieved from https://www.researchgate.net/publication/283712478_Application_of_Critical_Discourse_Analysis_in_Media_Discourse_Studies on October 28, 2018

Setiowati, E. \& Wahyuningtyas, B. (2011). Marjinalisasi Perempuan Pertama Melalui Lagu: Suatu Analisis Wacana Kritis Terhadap Lagu "Jadikan Aku yang Kedua. Humaniora Journal 2(2): 1006-1024. Retrieved from https://media.neliti.com/media/publications/166956ID-marjinalisasi-perempuan-pertama-melalui.pdf on October 13, 2018

Siswono. (2014). Teori dan Praktik Diksi. Jakarta: DeePublish

Peraturan Daerah Kota Malang No. 3 Tahun 2015 tentang Retribusi Jasa Umum. (2015)

Priyanto. (2016). Gaya Bahasa Berdasarkan Struktur Kalimat Dalam Pantun Adat Jambi. Pena Jurnal 6(1): 61-79. Retrieved from https://online-journal.unja.ac.id/pena/article/view/4743/3252 on December 12, 2019

Van Dijk, T.A. (2008). Discourse and Power. New York: Pallgrave Macmillan

Wodak, R. \& Mayer, M. (2001). Methods of Critical Discourse Anlysis. London: SAGE Publications 